\title{
Antibacterial evaluation of Some Synthesis Complexes of Azo-dye Ligands.
}

\author{
Rahman A. MohameedMurad ${ }^{* a}$, Aso H. Hasan ${ }^{\text {b }}$, Rokan D. Kareem \\ ${ }^{a}$ Department of Chemistry, College of Educational, Garmian University, Sulaimania, Iraq. \\ ${ }^{b}$ Department of Chemistry, College of Science, Garmian University, Sulaimania, Iraq. \\ ${ }^{c}$ Laboratory department, General Hospital of Kalar, Sulaimania, Iraq. \\ *E-mail: Rahmanazeez@garmian.edu.krd
}

\begin{abstract}
In present work, two ligands, azo Schiff-base (AZD1 and AZD2), were synthesized by two steps. Firstly, Schiff-bases were prepared by condensation of Salicyldehyde with anthranilic acid, followed by diazotization of aromatic amines and their subsequent coupling reaction with Schiffbases. Consequently, 8 complexes of the type $\left[\mathrm{M}(\mathrm{AZD1}) \mathrm{Cl}_{2}\right]$ and $\left[\mathrm{M}(\mathrm{AZD} 2) \mathrm{Cl}_{2}\right]$, where $\mathrm{M}=$ $\mathrm{Cu}(\mathrm{II}), \mathrm{Ni}(\mathrm{II}), \mathrm{Co}(\mathrm{II}), \mathrm{Mn}(\mathrm{II})$; were synthesized and characterized with the help of molar conductance, magnetic susceptibility measurements, FT-IR, micro elemental analysis , $\mathrm{H}^{1} \mathrm{NMR}$, and Uv-visible spectroscopy. The spectral data revealed that the ligands act as bidentate ligand, the hydroxyl of carboxylic group and the azo group in AZD1 and hydroxyl of phenyl group and the azomethin group in AZD2 ligand are co-ordination to the central metal atoms. Lastly, all the compounds were screened for their antibacterial activity, using well-diffusion method. In conclusion, the ligands and some of the complexes exhibited appreciable antibacterial activity against Escherichia coli Klebsiella pneumonia and Staphylococcus haemolyticus and Staphylococcus aurous.
\end{abstract}

KeyWords: Azo Schiff base, Azo Schiff base complexes, antibacterial activity and spectral studies.

\subsection{Introduction}

Azo Schiff base complexes contain both azo and azomethin groups. The azo group has an excellent, important application in coordination chemistry ${ }^{(1,2)}$. It is a highly sensitive organic reagent, suitable for the spectrophotometric determination of ions of transition elements in trace concentrations (3). They also have a wide application as metallochromic indicators for colorometric titration $^{(4)}$. 
These dyes are used in electrophotographic or sensor applications, lasers, electro-optical devices and ink-jet printers ${ }^{(5)}$.The coordination complexes of transition metals with azoligands are of current attraction due to the interesting physical, chemical, photophysical and photochemical, catalytic and different material properties ${ }^{(6)}$.

Azo compounds or dyes characterized by the presence of the azo moiety $(-\mathrm{N}=\mathrm{N}-)$ in their structure, conjugated with two, distinct or identical, mono- or polycyclic aromatic or hetero aromatic systems ${ }^{(7)}$. Previous studies have shown the antimicrobial activity of metal complexes against various pathogens including bacteria ${ }^{(8)}$. However, the antimicrobial activity of any synthetic metal complexes might be different and therefore, it should be revealed.

In the current study an azo dyes were synthesized from reaction of (2-amino-benzoic acid) with salicyldehyde and uses the (aniline or 4- nitroanilne) as coupling agent scheme (1). Then they were reacted with aniline and nitroaniline to prepare Schiff bases as ligands. In addition, complexes of this ligand with metal ions of $\mathrm{Cu}$ (II), $\mathrm{Ni}(\mathrm{II}), \mathrm{Co}$ (II)and $\mathrm{Mn}$ (II) have also been synthesized and characterized spectroscopically. Finally, the antimicrobial activity of these synthesized complexes was determined using disc diffusion assay.

\subsection{Experimental}

\subsection{Instrumentation}

The Uv-visible spectrophotometer was carried out in ethanol and water mixture as solvent by using the T50 (Shimadzu) spectrophotometer, FTIR spectrophotometer were taken on a (Shimadzu) infrared spectrophotometer in the (4000-400) $\mathrm{cm}^{-1}$ range. Melting points were measured using Stuart Digital Melting point apparatus. Elemental analysis was carried out on Perkin Elmer-2400 CHNS analyzer. The conductivities of the complexes were measured in ethanol and water mixture as solvent by using Conductometer type (Cond. 720) conductivity meter. In addition, magnetic measurements were recorded on an auto Magnetic Susceptibility balance Guoy method. Finally, Antibacterial evaluations were measured by using well diffusion methods against four types of bacteria.

\subsection{Materials and Reagents}

All the chemicals used were of reagent grade and procured from Sigma-Aldrich and Fluka. Metal salts (B.D.H) were commercially available as pure samples and solvents were used as received. 


\subsection{Preparation of the Ligands}

The ligands were prepared according to the procedure ${ }^{(9)}$.

\subsubsection{Preparation of Schiff bases (starting materials) (A1)}

A mixture of (2-amino benzoic acid) $(0.05 \mathrm{~mol})$ and Salicyldehyde $(3.425 \mathrm{gm}, 0.05 \mathrm{~mol})$ in $96 \%$ ethanol $(50 \mathrm{~mL})$ with few drops of glacial acetic acid was stirred for 1 hour. The precipitate was filtrated, washed several times with ethanol and dried to give Salicylidene 2- aminobenzoic acid (A1). The reaction is shown in Scheme 1.

\subsubsection{Synthesis of Azo Schiff base ligands (dyes) (AZD1 and AZD2)}

$(0.01 \mathrm{~mol})$ of (aniline or 4- nitroanilne) was gently heated in $(1.7 \mathrm{~mL})$ Cone. $\mathrm{HCl}$ and then $(10 \mathrm{~mL})$ of distilled water was added. The solution was then cooled to $\left(0-5^{\circ} \mathrm{C}\right)$ in an ice-bath and maintained at this temperature. Sodium nitrite $(0.69 \mathrm{gm})$ solution in water $(5 \mathrm{~mL})$ was then added dropwise The diazonium solution was added portion wise to the coupling component solution prepared by mixing of (A1) $(0.01 \mathrm{~mol})$ in water with sodium hydroxide $(1.5 \mathrm{gm})$ dissolve in (100 $\mathrm{mL}$ ) of water. The mixture was stirred for $30 \mathrm{~min}$. The precipitated crude dyes were formed, collected by filtration and washed with water and ethanol ${ }^{(10)}$. The reaction is shown in Scheme (1). The physical properties of compounds were given in Table 1.

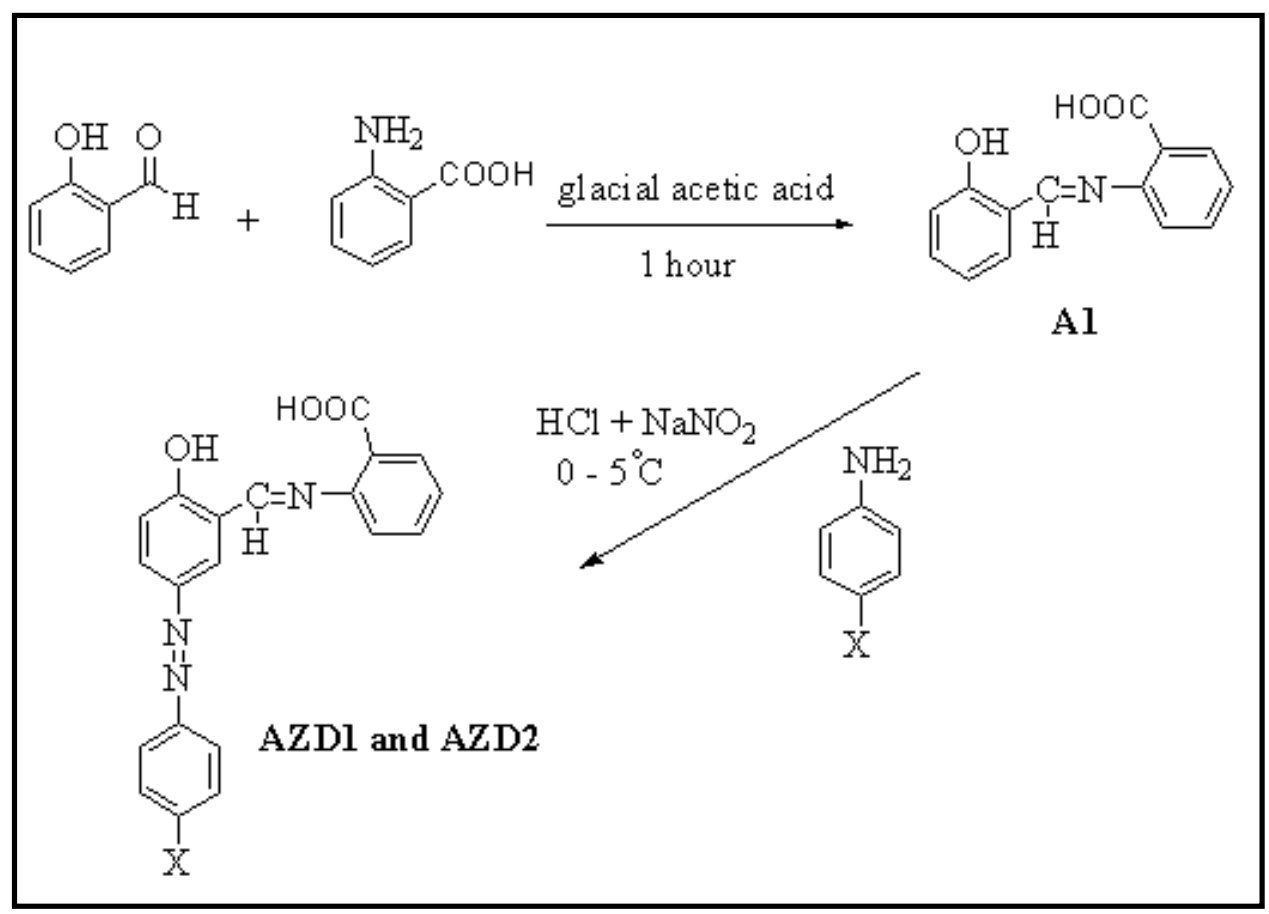

Scheme 1: Preparation of Ligands AZD1 and AZD2. 
Table 1: Same physical properties of starting materials

\begin{tabular}{|c|c|c|c|c|c|c|}
\hline No. & Compound & $\begin{array}{c}\text { Attached } \\
\text { group }\end{array}$ & $\begin{array}{c}\text { Chem. } \\
\text { Formula }\end{array}$ & $\begin{array}{c}\text { Mol. } \\
\text { Weight }\end{array}$ & $\begin{array}{c}\text { Yield } \\
\text { \% }\end{array}$ & Colour \\
\hline $\mathbf{1}$ & $\mathrm{A} 1$ & & $\mathrm{C}_{14} \mathrm{H}_{11} \mathrm{NO}_{3}$ & 241.242 & 75.5 & Bright - Yellow \\
\hline $\mathbf{2}$ & $\mathrm{AZD} 1$ & $\mathrm{X}: 4-\mathrm{H}$ & $\mathrm{C}_{20} \mathrm{H}_{15} \mathrm{~N}_{3} \mathrm{O}_{3}$ & 345.351 & 85 & Brown \\
\hline $\mathbf{3}$ & AZD2 & $\mathrm{X}: 4-\mathrm{NO}_{2}$ & $\mathrm{C}_{20} \mathrm{H}_{14} \mathrm{~N}_{4} \mathrm{O}_{5}$ & 390.349 & 74 & Reddish- brown \\
\hline
\end{tabular}

\subsubsection{Synthesis of Metal Complexes (General procedure):}

An ethanolic solution of the ligands (AZD1 and AZD2) (1 mmol) (25 mL) was added gradually to the ethanolic solution $(10 \mathrm{~mL})(1 \mathrm{mmol})$ of $\mathrm{CuCl}_{2} \cdot 6 \mathrm{H}_{2} \mathrm{O}, \mathrm{NiCl}_{2} \mathrm{CoCl}_{2}$ and $\mathrm{MnCl}_{2} 4 \mathrm{H}_{2} \mathrm{O}$ respectively. i.e. (1:1) mole ratio for (metal to ligand). Then added 3 drops of triethylamine (TEA). The mixture was left under reflux with continuous stirring about (3-4) hours or about 1 day where upon the solid complexes precipitated. The resulting solid was washed with ethanol followed by diethyl ether and dried in a vacuum over anhydrous $\mathrm{CaCl}_{2}$.

\subsection{Antibacterial Activity:}

The bacterial strains were isolated by culturing from patients in Kalar General Hospital. The Mueller Hinton agar plates were cultured with $50 \mu \mathrm{l}$ of each type of bacteria (E.coli and Staphylococcus aurous) with $\mathrm{OD}_{600}=0.2$ and were provided with (5) $\mathrm{cm}$ holes. The holes were loaded with (50) $\mu \mathrm{l}$ of all metal complexes and ligands, and the plates were incubated at $37{ }^{0} \mathrm{C}$ for (24) hours. Meropenem antibiotic was used as positive control and the solvent as a negative control. The diameter of the wells with inhibition zones were measured using ruler. The data were arranged in table (5).

\subsection{Results and Discussion:}

The structures of the ligand and the complexes were established from their Uv-Visible, FT- IR, elemental analyses, and magnetic susceptibility measurements. The complexes are intensely colored stable solids; the metal complexes exhibit (1:1) metal to ligand stoichiometry, table (2). Molar conductivities of all synthesized complexes are listed in table (2), which

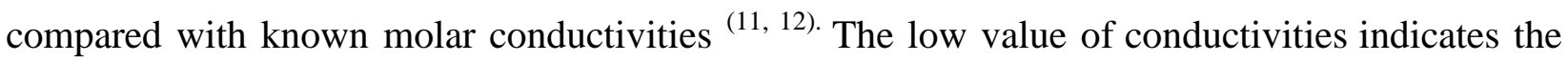
non-electrolyte nature of complexes. 
Table (2): Color, melting point, elemental analysis and conductivity data for the synthesized azo- Schiff base metal complexes.

\begin{tabular}{|c|c|c|c|c|c|c|}
\hline \multirow[t]{2}{*}{ No. } & \multirow[t]{2}{*}{ Compound } & \multirow{2}{*}{$\begin{array}{c}\text { Color } \\
\left(\text { M.P). }\left({ }^{\circ} \mathrm{C}\right)\right.\end{array}$} & \multicolumn{3}{|c|}{$\begin{array}{c}\text { Found } \\
\text { (Calculated)\% }\end{array}$} & \multirow{2}{*}{$\underset{\left(\begin{array}{c}\mathbf{m} \Lambda \\
\left(\mathbf{\Omega}^{-1} . \mathbf{c m}^{-1}\right)\end{array}\right.}{\left.\mathbf{m o l}^{-1}\right)}$} \\
\hline & & & $C \%$ & H\% & $N \%$ & \\
\hline & Ligand(AZD1) & $\begin{array}{c}\text { orange } \\
(182)\end{array}$ & $\begin{array}{c}62.01 \\
(61.38)\end{array}$ & $\begin{array}{c}3.98 \\
(3.86)\end{array}$ & $\begin{array}{l}13.76 \\
(14.32)\end{array}$ & \\
\hline 1 & {$\left[\mathrm{Cu}(\mathrm{AZD} 1) \mathrm{Cl}_{2}\right]$} & $\begin{array}{c}\text { Deep-Brown } \\
\text { (324) }\end{array}$ & $\begin{array}{c}46.04 \\
(45.77)\end{array}$ & $\begin{array}{c}3.02 \\
(2.79)\end{array}$ & $\begin{array}{c}9.18 \\
(10.65)\end{array}$ & 1 \\
\hline 2 & {$\left[\mathrm{Ni}(\mathrm{AZD} 1) \mathrm{Cl}_{2}\right]$} & $\begin{array}{c}\text { Orange-yellow } \\
(234)\end{array}$ & $\begin{array}{c}45.94 \\
(46.20)\end{array}$ & $\begin{array}{c}3.00 \\
(2.71)\end{array}$ & $\begin{array}{c}11.02 \\
(10.78)\end{array}$ & 1,5 \\
\hline 3 & {$\left[\mathrm{Co}(\mathrm{AZD} 1) \mathrm{Cl}_{2}\right]$} & $\begin{array}{l}\text { Deep-Brown } \\
\text { (221) }\end{array}$ & $\begin{array}{l}45.33 \\
(46.1)\end{array}$ & $\begin{array}{c}2.93 \\
(2.70)\end{array}$ & $\begin{array}{c}9.54 \\
(10.77)\end{array}$ & 1.9 \\
\hline 4 & {$\left[\mathrm{Mn}(\mathrm{AZD} 1) \mathrm{Cl}_{2}\right]$} & $\begin{array}{c}\text { Brown } \\
(156)\end{array}$ & $\begin{array}{c}45.98 \\
(46.54)\end{array}$ & $\begin{array}{c}2.65 \\
(3.97)\end{array}$ & $\begin{array}{l}11.03 \\
(10.85)\end{array}$ & 7.2 \\
\hline & Ligand (AZD2) & $\begin{array}{c}\text { Brown } \\
(106)\end{array}$ & $\begin{array}{c}60.95 \\
(61.38)\end{array}$ & $\begin{array}{c}3.27 \\
(3.86)\end{array}$ & $\begin{array}{c}15.01 \\
(14.32)\end{array}$ & \\
\hline 5 & {$\left[\mathrm{Cu}(\mathrm{AZD} 2) \mathrm{Cl}_{2}\right]$} & $\begin{array}{c}\text { Orange- Brown } \\
(243)\end{array}$ & $\begin{array}{c}50.87 \\
(51.05)\end{array}$ & $\begin{array}{c}3.59 \\
(3.15)\end{array}$ & $\begin{array}{l}9.18 \\
(8.7)\end{array}$ & 10.9 \\
\hline 6 & {$\left[\mathrm{Ni}(\mathrm{AZD} 2) \mathrm{Cl}_{2}\right]$} & $\begin{array}{c}\text { Orange- Brown } \\
(122)\end{array}$ & $\begin{array}{c}50.27 \\
(50.12)\end{array}$ & $\begin{array}{c}3.05 \\
(3.18)\end{array}$ & $\begin{array}{c}8.99 \\
(8.10)\end{array}$ & 1.3 \\
\hline 7 & {$\left[\mathrm{Co}(\mathrm{AZD} 2) \mathrm{Cl}_{2}\right]$} & $\begin{array}{l}\text { Orange } \\
(154)\end{array}$ & $\begin{array}{c}49.00 \\
(50.92)\end{array}$ & $\begin{array}{c}2.93 \\
(3.18)\end{array}$ & $\begin{array}{l}9.03 \\
(8.10)\end{array}$ & 1.8 \\
\hline 8 & {$\left[\mathrm{Mn}(\mathrm{AZD} 2) \mathrm{Cl}_{2}\right]$} & $\begin{array}{c}\text { Brown } \\
(124)\end{array}$ & $\begin{array}{c}46.56 \\
(50.9)\end{array}$ & $\begin{array}{c}3.94 \\
(3.20)\end{array}$ & $\begin{array}{c}9.4 \\
(8.92)\end{array}$ & 1.2 \\
\hline
\end{tabular}

\subsection{Electronic spectra and magnetic moment:}

The absorption bands at 45455 and $31250 \mathrm{~cm}^{-1}$ attributed to $(\pi \rightarrow \pi *)$ and $(\mathrm{n} \rightarrow \pi *)$ transition respectively originating from the azo Schiff base ligand and carboxylic group are observed in the spectrum of the free ligand. ${ }^{(11)}$. The data arranged in table (3)

The observed magnetic moment of the $\mathrm{Cu}(\mathrm{II})$ complex (1 and 4) is 1.94 and 1.95 B.M. respectively, which confirms the square planar structure of these complex. Electronic spectrum of the $\mathrm{Cu}$ (II) complex displays bands in range (46511- 23809 ) $\mathrm{cm}^{-1}$. May be assigned to the charge transfer transitions ${ }^{(12)}$. The electronic spectrum of the orange yellow color complexes of Ni(II) ion (i.e. 2 and 6), has a strong band in range $(22,222-45455) \mathrm{cm}^{-1}$ located inside the experimental value at $\left(15,000-25,000 \mathrm{~cm}^{-1}\right)$ of square planar geometry. This band ascribe to $\left({ }^{1} A_{1} g \rightarrow{ }^{1} A_{2} g\right)$ transition. The magnetic measurements come also to confirm the square planar structure with a diamagnetic value ${ }^{(13)}$.

For $\mathrm{Co}(\mathrm{II})$ complexes (3) exhibit tow band at (22222 and 45455) assigned to charge transfer transitions of tetrahedral geometry. While Co(II) complexes (7), two bands at (45454 and 25000) 
$\mathrm{cm}^{-1}$ assigned to charge transfer and ${ }^{4} \mathrm{~A}_{2}(\mathrm{~F}) \rightarrow{ }^{4} \mathrm{~T}_{1}(\mathrm{~F})$ transitions, respectively. The effective magnetic moment for a tetrahedral Co(II) species is 4.06 B.M., while the calculated value is 3,93 and 3.89 B.M. for ( 3 and 7) respectively, this give a close matching data between experimental and theoretical data ${ }^{(14)}$.

The spectra of the complexes of $\mathrm{Mn}$ (II) shows an intense bands in range $(23800-47615) \mathrm{cm}^{-1}$ of tetrahedral geometry may be assigned to charge transfer transitions ${ }^{(13,15)}$. The data of magnetic susceptibility confirm with the 5 unpaired electrons in $\mathrm{d}^{5}$ system for metal complexes.

Table (3): The electronic and magnetic properties data for azo-Schiff base ligands and its metal complexes.

\begin{tabular}{|c|c|c|c|c|c|}
\hline \multirow{2}{*}{ No. } & \multirow{2}{*}{ Compounds } & \multicolumn{2}{|c|}{ Band absorption } & \multirow{2}{*}{ Assignment } & \multirow{2}{*}{ 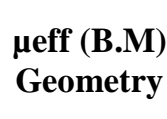 } \\
\hline & & $\mathrm{cm}^{-1}$ & $\mathbf{n m}$ & & \\
\hline & \multirow{2}{*}{ Ligand (AZD1) } & 31250 & $\underline{320}$ & $\pi \rightarrow \pi *$ & \\
\hline & & $\overline{45450}$ & $\overline{235}$ & $\mathrm{n} \rightarrow \pi *$ & \\
\hline \multirow{3}{*}{1} & \multirow{3}{*}[\mathrm{Cu}(\mathrm{AZD}1)\mathrm{Cl}_{2}]{} & $\overline{46511}$ & $\overline{215}$ & $C T$ & \multirow{3}{*}{1.94 S.P. } \\
\hline & & 40000 & 250 & $C T$ & \\
\hline & & 23809 & 420 & $C T$ & \\
\hline \multirow{2}{*}{2} & \multirow{2}{*}[\mathrm{Ni}(\mathrm{AZD}1)\mathrm{Cl}_{2}]{} & 45455 & 220 & $C T$ & \multirow{2}{*}{$\underline{0}$ S.P. } \\
\hline & & 22222 & 450 & ${ }^{I} A_{1} g \rightarrow{ }^{I} A_{2} g$ & \\
\hline \multirow{2}{*}{3} & \multirow{2}{*}[\mathrm{Co}(\mathrm{AZD}1)\mathrm{Cl}_{2}]{} & 45455 & 220 & $C T$ & \multirow{2}{*}{ 3.93 T.h. } \\
\hline & & 22222 & 435 & $C T$ & \\
\hline \multirow{5}{*}{4} & \multirow{3}{*}[\mathrm{Mn}(\mathrm{AZD}1)\mathrm{Cl}_{2}]{} & 47619 & 210 & $C T$ & \multirow{3}{*}{4.95 T.h. } \\
\hline & & 40000 & 250 & $C T$ & \\
\hline & & 23809 & 420 & $C T$ & \\
\hline & \multirow{2}{*}{ Ligand (AZD2) } & $\mathbf{4 5 4 5 5}$ & $\underline{220}$ & $\pi \rightarrow \pi *$ & \\
\hline & & 23809 & 420 & $\mathrm{n} \rightarrow \pi *$ & \\
\hline \multirow{3}{*}{5} & \multirow{3}{*}[\mathrm{Cu}(\mathrm{AZD}2)\mathrm{Cl}_{2}]{} & $\overline{40000}$ & $\overline{250}$ & $C T$ & \multirow{3}{*}{$\underline{1.95 \text { S.P. }}$} \\
\hline & & 33333 & 300 & $C T$ & \\
\hline & & 25000 & 400 & $C T$ & \\
\hline \multirow{2}{*}{6} & \multirow{2}{*}[\mathrm{Ni}(\mathrm{AZD}2)\mathrm{Cl}_{2}]{} & 45455 & 220 & $C T$ & \multirow{2}{*}{ 0 S.P. } \\
\hline & & 25000 & 400 & ${ }^{I} A_{1} g \rightarrow{ }^{I} A_{2} g$ & \\
\hline \multirow{2}{*}{7} & \multirow{2}{*}[\mathrm{Co}(\mathrm{AZD}2)\mathrm{Cl}_{2}]{} & 43478 & 230 & $C T$ & \multirow{2}{*}{$\underline{3.89}$ T.h. } \\
\hline & & 25000 & 400 & ${ }^{4} \mathrm{~A}_{2}(\mathrm{~F}) \rightarrow{ }^{4} \mathrm{~T}_{1}(\mathrm{~F})$ & \\
\hline \multirow{3}{*}{8} & \multirow{3}{*}[\mathrm{Mn}(\mathrm{AZD}2)\mathrm{Cl}_{2}]{} & 47619 & 210 & $C T$ & \\
\hline & & 40000 & 250 & $C T$ & \\
\hline & & 23809 & 420 & $C T$ & \\
\hline
\end{tabular}

\subsection{Infra-Red Spectroscopy}

The infrared spectra assignment of the proposed structures of the Schiff base of azo-dye complexes was made through consideration of their infrared spectra. The IR spectra of the free ligand and metal complexes (Table 4) were carried out in the range $4000-400 \mathrm{~cm}^{-1}$. The IR 
spectrum of the all metal complex of( AZD1) ligand shows a sharp bands in range ( $1442-1460)$ $\mathrm{cm}^{-1}$, attributed to $v(-\mathrm{N}=\mathrm{N}-)$ stretching frequency of azo-dye ${ }^{(16)}$, which are shifted to higher frequency on going from the free ligand (at $1444 \mathrm{~cm}^{-1}$ ). This is indicative of the coordination of the imine nitrogen to the metal. In the free ligands, the sharp bands observed in the range (3284) $\mathrm{cm}^{-1}$ is due to $v(\mathrm{OH})$ stretching frequency of carboxylic group ${ }^{(15)}$. In all complexes were moved to lower frequencies.

While IR spectra of the ligand (AZD2) exhibit band at (3219) $\mathrm{cm}^{-1}$, which was assigned to the stretching vibration of $(\mathrm{OH})$ phenol group ${ }^{(15)}$, while for all complexes are appear in range (3197$3205) \mathrm{cm}^{-1}$ were shifted to lower frequency with change in shape in spectra of complexes, which is an indication of the engagement of this group in the coordination with the metal ion. The band in range (1587-1589) $\mathrm{cm}^{-1}$ for metal complexes are due to $v(\mathrm{C}=\mathrm{N})$ stretching frequency of azomethin group, but for free ligand it appear at (1595) cm-1 shifted to lower frequency, which is an indication of the engagement of this group in the coordination with the metal ions. Metal oxygen, nitrogen and halogen bands further confirmed by the presence of the bands around (400422), (447-469) and (526-586) $\mathrm{cm}^{-1}(16,17)$ respectively.

Table (4): Selected IR bands of the azo- Schiff base ligands and its metal complexes $\left(\mathrm{cm}^{-1}\right)$.

\begin{tabular}{|c|c|c|c|c|c|c|c|c|}
\hline No. & Compounds & $\begin{array}{l}\stackrel{0}{0} \\
\stackrel{1}{\Xi}\end{array}$ & 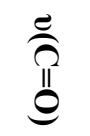 & 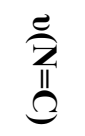 & $\underset{\underset{Z}{Z}}{\stackrel{\Xi}{Z}}$ & 艿 & $\stackrel{\stackrel{2}{2}}{\stackrel{3}{\varrho}}$ & $\stackrel{\stackrel{e}{2}}{\stackrel{3}{\Omega}}$ \\
\hline & Ligand(AZD1) & 3284 & 1697 & 1599 & 1425 & & & \\
\hline 1 & {$\left[\mathrm{Cu}(\mathrm{AZD} 1) \mathrm{Cl}_{2}\right]$} & 3275 & $\begin{array}{ll}---- \\
\end{array}$ & 1603 & 1444 & 422 & 460 & 534 \\
\hline 2 & {$\left[\mathrm{Ni}(\mathrm{AZD} 1) \mathrm{Cl}_{2}\right]$} & 3305 & 1700 & 1593 & 1448 & 410 & 447 & 526 \\
\hline 3 & {$\left[\mathrm{Co}(\mathrm{AZD} 1) \mathrm{Cl}_{2}\right]$} & 3307 & 1705 & 1596 & 1442 & 407 & 453 & 532 \\
\hline \multirow[t]{2}{*}{4} & {$\left[\mathrm{Mn}(\mathrm{AZD} 1) \mathrm{Cl}_{2}\right]$} & 3305 & 1700 & 1595 & 1460 & 407 & 459 & 560 \\
\hline & Ligand (AZD2) & 3219 & 1734 & 1595 & 1441 & & & \\
\hline 5 & {$\left[\mathrm{Cu}(\mathrm{AZD} 2) \mathrm{Cl}_{2}\right]$} & 3199 & 1733 & 1585 & 1437 & 402 & 465 & 586 \\
\hline 6 & {$\left[\mathrm{Ni}(\mathrm{AZD} 2) \mathrm{Cl}_{2}\right]$} & 3203 & 1703 & 1587 & 1441 & 400 & 462 & 534 \\
\hline 7 & {$\left[\mathrm{Co}(\mathrm{AZD} 2) \mathrm{Cl}_{2}\right]$} & 3197 & ---- & 1589 & 1441 & 402 & 469 & 530 \\
\hline 8 & {$\left[\mathrm{Mn}(\mathrm{AZD} 2) \mathrm{Cl}_{2}\right]$} & 3205 & ----- & 1589 & 1437 & 402 & 461 & 526 \\
\hline
\end{tabular}

\subsection{Antibacterial activity:}

In vitro antibacterial screening was performed by the agar disc diffusion method. The bacterial species used in the screening were gram-negative bacteria Escherichia coli, Klebsiella 
pneumonia and gram-positive bacteria Staphylococcus aurous and Staphylococcus haemolyticus. The data are organized in table (5).

The free ligand (AZD1), (3) and (4) were sensitive against Escherichia coli. The free ligand (AZD1 and AZD2) (2), (5) and (8) were sensitive against Staphylococcus aurous. While the other complexes were resistant against Klebsiella pneumonia and Staphylococcus haemolyticus.

Table 5: Bacterial activity of ligands and its metal complexes

\begin{tabular}{|c|c|c|c|c|c|}
\hline No. & Compound & Escherichia coli & $\begin{array}{c}\text { Klebsiella } \\
\text { pneumonia }\end{array}$ & $\begin{array}{c}\text { Staphylocous } \\
\text { aureus }\end{array}$ & $\begin{array}{c}\text { Staphylococcus } \\
\text { haemolyticus }\end{array}$ \\
\hline & $\mathrm{Ligand}(\mathrm{AZD} 1)$ & $25 \mathrm{~mm}$ & $\mathrm{R}$ & $20 \mathrm{~mm}$ & $\mathrm{R}$ \\
\hline 1 & {$\left[\mathrm{Cu}(\mathrm{AZD} 1) \mathrm{Cl}_{2}\right]$} & $\mathrm{R}$ & $\mathrm{R}$ & $\mathrm{R}$ & $\mathrm{R}$ \\
\hline 2 & {$\left[\mathrm{Ni}(\mathrm{AZD} 1) \mathrm{Cl}_{2}\right]$} & $\mathrm{R}$ & $\mathrm{R}$ & $1 \mathrm{~mm}$ & $\mathrm{R}$ \\
\hline 3 & {$\left[\mathrm{Co}(\mathrm{AZD} 1) \mathrm{Cl}_{2}\right]$} & $18 \mathrm{~mm}$ & $\mathrm{R}$ & $\mathrm{R}$ & $\mathrm{R}$ \\
\hline 4 & {$\left[\mathrm{Mn}(\mathrm{AZD} 1) \mathrm{Cl}_{2}\right]$} & $27 \mathrm{~mm}$ & $\mathrm{R}$ & $\mathrm{R}$ & $\mathrm{R}$ \\
\hline & $\mathrm{Ligand}(\mathrm{AZD} 2)$ & $\mathrm{R}$ & $\mathrm{R}$ & $3 \mathrm{~m}$ & $\mathrm{R}$ \\
\hline 5 & {$\left[\mathrm{Cu}(\mathrm{AZD} 2) \mathrm{Cl}_{2}\right]$} & $\mathrm{R}$ & $\mathrm{R}$ & $25 \mathrm{~mm}$ & $\mathrm{R}$ \\
\hline 6 & {$\left[\mathrm{Ni}(\mathrm{AZD} 2) \mathrm{Cl}_{2}\right]$} & $\mathrm{R}$ & $\mathrm{R}$ & $\mathrm{R}$ & $\mathrm{R}$ \\
\hline 7 & {$\left[\mathrm{Co}(\mathrm{AZD} 2) \mathrm{Cl}_{2}\right]$} & $\mathrm{R}$ & $\mathrm{R}$ & $\mathrm{R}$ & $\mathrm{R}$ \\
\hline 8 & {$\left[\mathrm{Mn}(\mathrm{AZD} 2) \mathrm{Cl}_{2}\right]$} & $\mathrm{R}$ & $\mathrm{R}$ & $5 \mathrm{~mm}$ & $\mathrm{R}$ \\
\hline
\end{tabular}

\section{Conclusion}

This study has reported the synthesis and characterization of two Azo - Schiff base ligands containing (-N=N-) group, namely -\{[2-Hydroxy-5-(4-nitro-phenylazo)-benzylidene $]$-amino $\}$ benzoic acid (AZD1), 2-\{[2-Hydroxy-5-(4-nitro-phenylazo)-benzylidene]-amino $\}$-benzoic acid (AZD2).A novel ligands and its $\mathrm{Cu}(\mathrm{II}), \mathrm{Ni}$ (II), $\mathrm{Co}$ (II) and $\mathrm{Mn}$ (II) complexes were synthesized and characterized by various spectroscopic techniques. The results showed tetrahedral and square planer geometry around of the complexes with mole ratio (1:1) metal: ligand. According to Uvvisible spectroscopy, elemental analysis, IR spectroscopy, melting point, conductivity and magnetic susceptibility data the following structures are proposed for the synthesized metal complexes as shown in figure (1). 


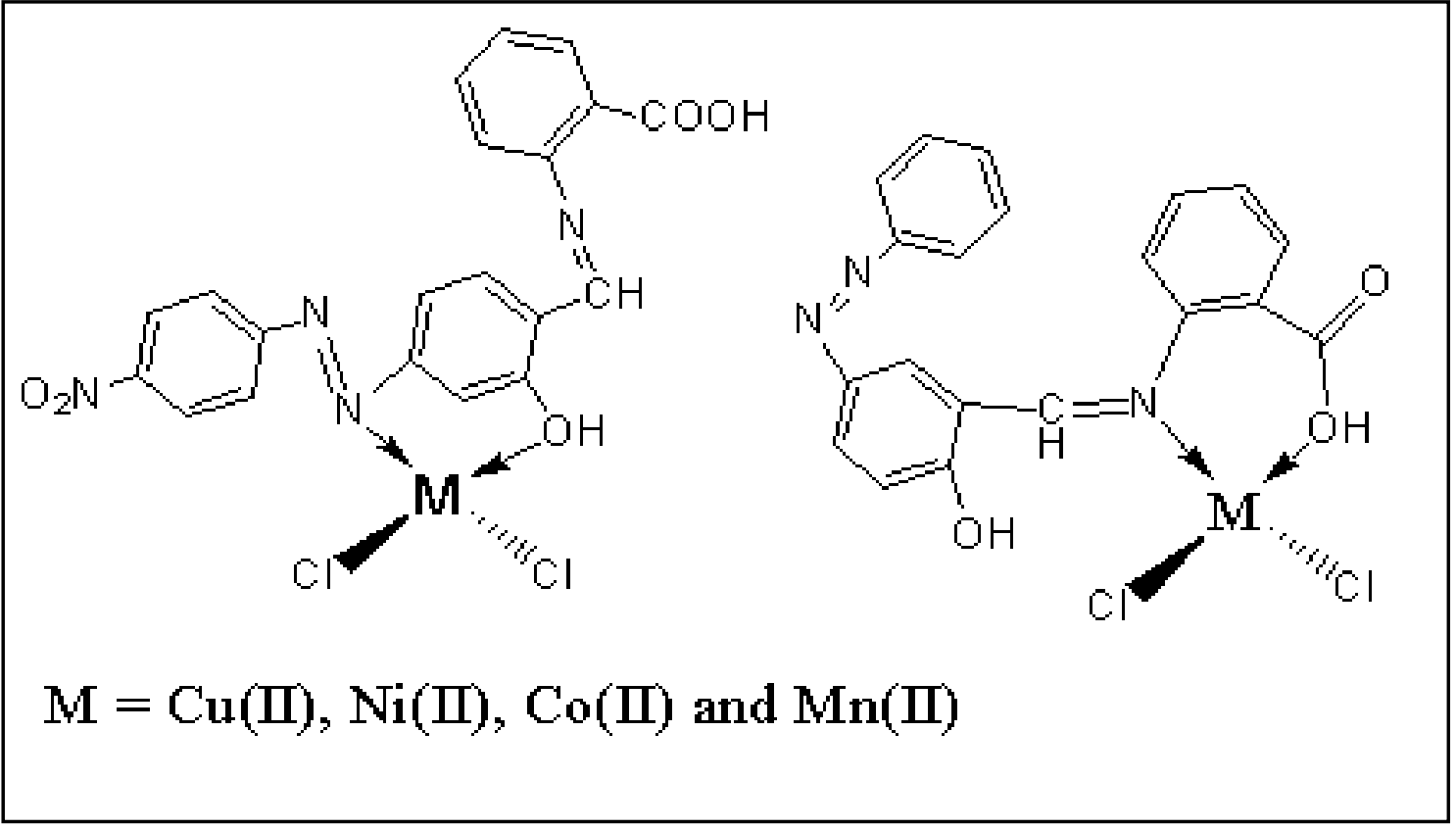

Figure (1): Proposed chemical structure for metal complexes.

\section{Acknowledgement:}

We wish to thank D. Sherko Subhan Niranji for his advice during performing the antibacterial screening method.

\section{References}

1- Raziyeh Arab Ahmadi and Saeid Amani, Synthesis, Spectroscopy, Thermal Analysis, Magnetic Properties and Biological Activity Studies of $\mathrm{Cu}$ (II) and $\mathrm{Co}(\mathrm{II})$ Complexes with Schiff Base Dye Ligands, Molecules 2012, 17, 6434-6448.

2- Hudson, S.A.; Maitlis, P.M. Calamitic metallomesogens: Metal-containing liquid crystals with rodlike shapes. Chem. Rev. 1993, 93, 861-885.

3- S. B. Savvin, V. P. Ded Kova and D. P. Shvoeva; Russ. Chem. Rev, 69 (2000) 187200.

4- J. M. Veauthier, E. J. Schelter, C. J. Kuehl, A. E. Clark and B. D. John; Inorganic Chem., 44 (2005) 5911.).

5- E.Yildiz and H.Boztepe., Synthesis of Novel Acidic Mono Azo Dyes and an Investigation of Their Use in Textile Industry.Turk Journal of Chem.26, 897-903, 2002

6- [K.R.Raghavendra and K.Ajay Kumar, Synthesis Of Some Novel Azo Dyes And Their Dyeing, Redox And Antifungal Properties . Int. J. of Chem.Tech. Res., 5 ,4 , 17561760,2013.

7- Swati, Ginni, Romila, Karnawat, I.K.Sharma, P.S.Verma, (2011). Synthesis, Characterzation and antimicrobial screening of applied biology and pharmaceutical technology, 2(2) 332 . 
8- Pahontu, E., F. Julea, T. Rosu , V. Purcarea, Y. Chumakov, P. Petrenco, A. Gulea. Antibacterial, antifungal and in vitro antileukaemia activity of metal complexes with thiosemicarbazones. J. Cell. Mol. Med.19, (4): 865-878. (2015). Doi: 10.1111/jcmm.12508.

9- Hasan, A. H. and MohameedMurad, R. A. (2017). Synthesis and Characterization of Some New Heavy Metal Complexes with Azo-Schiff Base Ligands. Journal of Garmin University. 12 (1).118-127. doi.org/10.24271/garmian.5

10- Asieh Yahyazadeh and Vahid Azimi, SYNTHESIS OF SOME UNSYMMETRICAL NEW SCHIFF BASES FROM AZO DYES, Eur. Chem. Bull., 2(7), 453-455, 2013.

11-C. Anitha, S. Sumathi, P. Tharmaraj,and C. D. Sheela, Synthesis, Characterization, and Biological Activity of Some TransitionMetal Complexes Derived from Novel Hydrazone Azo Schiff Base Ligand, Hindawi Publishing Corporation, International Journal of Inorganic Chemistry, Article ID 493942, 2011.

12- Hoda A. Bayoumi, Abdel-Nasser M.A. Alaghaz and Mutlak Sh. Aljahdali, Cu(II), Ni(II), $\mathrm{Co}$ (II) and $\mathrm{Cr}$ (III) Complexes with N2O2-Chelating Schiff's Base Ligand Incorporating Azo and Sulfonamide Moieties: Spectroscopic, Electrochemical Behavior and Thermal Decomposition Studies, Int. J. Electrochem. Sci., 8 (2013) 9399 - 9413.

13- Moamen S. Refat, Mohamed Y. El-Sayed, Abdel Majid A. Adam, Cu(II), Co(II) and $\mathrm{Ni}(\mathrm{II})$ complexes of new Schiff base ligand: Synthesis, thermal and spectroscopic characterizations, Journal of Molecular Structure 1038 (2013) 62-72.

14- A.A.M. Belal 1, I.M. El-Deen1, N.Y. Farid 1, Rosan Zakaria 1 and Moamen S. Refat, Synthesis, spectroscopic, coordination and biological activities of some transition metal complexes containing ONO tridentate Schiff base ligand, Spectrochimica Acta Part A: Molecular and Biomolecular Spectroscopy (2015).

15- Oforka, N.C.; Mkpenie, V.N. A new method of synthesis of azo Schiff base ligands with azo and azomethine donors: Synthesis of $N$-4-methoxy-benzylidene-2-(3 hydroxyphenylazo)-5-hydroxyaniline and its nickel(II) complex. Chin. J. Chem. 2007, 25, 869-871.

16- Camilla Moretto dos Reis, Danilo Sousa Pereira, Rojane de Oliveira Paiva Lucimar Ferreira Kneipp and Aurea Echevarria, Molecules, 16, 10668-10684, (2011).

17- Omima M.I. Adly, Spectrochimica Acta Part A, 79, 1295- 1303 (2011). 